\title{
The Importance of Energy Sources in the Prevention of Environmental Pollution
}

\author{
Mustafa Caner TIMUR ${ }^{1}$, Zehra DOĞAN-ÇALIŞKAN ${ }^{2}$
}

\begin{abstract}
${ }^{1}$ ResearchAssistant, Ardahan University, Faculty of EconomicsandAdministrativeSciences, EconomicsDepartment
${ }^{2}$ AssociateProfessor, Abant İzzet Baysal University, Gerede Applied Sciences Faculty, International Tradeand Logistic

Department
\end{abstract}

\begin{abstract}
Since the existence of human beings, people have begun to change their surroundings and the shape of environment according to their life habits. This altering effort, which is embarked to provide better life conditions, has resulted in devastation of environment and other creatures. In the beginning the subject was only the environmental pollution of the cities, especially after the industrial revolution the demand for raw materials and the energy hunger, as a result of processing massive amounts of underground and surface resources that result of massive and global environmental pollution that has moved to such a crucial point that it has not reached that day. Nowadays, the significant part of the environmental
\end{abstract}

pollution is still emerging during the efforts of the society to obtain energy, despite developing technology, efficient tools and increasing environmental awareness. In this study, the reduction of environmental pollution during the efforts of our society to obtain energy should be placed in the conclusions in terms of importance and role for preferred energy resources.

Keywords- Environmental Economics, Energy, Valuation of Environmental Effects

Jel codes: Q5, Q4, Q510

Scope: Environmental Economy

Type: Research

\section{Çevre Kirliliğinin ÖnlenmesindeEnerji Kaynaklarının Önemi} Mustafa Caner TIMMUR

Araştırma Görevlisi, Ardahan Üniversitesi, İktisadi ve İdari Bilimler Fakültesi, İktisat.

\section{Zehra DOĞAN ÇALIŞKAN}

Yardımcı Doçent Doktor, Abant İzzet Baysal Üniversitesi, Gerede Uygulamalı Bilimler Y.O., Uluslararası Ticaret

Özet- Insanoğlu tarih sahnesine çıktığından itibaren diğer canlılardan farkl olarak çevresini değiştirmeye ve yaşadı̆̆ ortamı kendi yaşam alışkanlıklarına göre şekillendirmeye başlamıştır. Birçok kez daha iyi yaşam koşulları sağlamak adına giriştiği bu değiştirme çabası, dünya üzerinde yaşayan diğer canllara ve çevresel tahribata yol açarak sonuçlanmıştır. Daha önceleri sadece kentlerin çevresel kirlilikleri söz konusuyken; özellikle sanayi devrimi sonrasında ortaya çıkan hammadde ve enerji talebi sonucu yer altı ve yer üstü kaynakların yoğun miktarda işlenmesi çevre kirliliği kavramını o güne değin olmadığ noktaya taşımıştır. Gelişen teknolojiye, verimli araçlara ve artan çevre bilincine ră̆men; günümüzde çevre kirliliğinin önemli bir bölümü halen toplumun enerji elde etme çabaları sırasında ortaya çıkmaktadır. Bu çalışmada, toplumumuzun enerji elde etme çabaları esnasında ortaya çıkan çevre kirliliğinin azaltılmasında tercih edilen enerji kaynaklarının önemi ve rolüne ilişkin çıkarımlara yer verilmesi amaçlanmıştır.
AnahtarKelimeler- ÇevreEkonomisi, Enerji, ÇevreselEtkilerinDeğerlendirilmesi.

JelKodları: Q5, Q4, Q510

Alanı: ÇevreEkonomisi

Türü: Araştırma

Yayına Kabul Tarihi:

\section{INTRODUCTİON}

The concept of environmental pollution according to the definition made by Turkish Language Institution defined as"As a result of excessive or improper use and destruction of natural resources, the balance in the environment is deteriorating in the negative direction and some problems arise". Misuse of the resources thatcauseenvironmentalpollutionresults in undesirablesubstances.

These materials are called "Waste" and can be used for materials such as food waste, newspapers, bottles, construction excavations in daily life. Where raw materials and energy are used in all areasa few waste is ensued. These items are generally categorized as having 
lost

theirvalueafterproductionactivitiesorundesirablesubstance sbyoreowner(King, 2010: 109).

Unlike the wastes that human activities reveal, it can be claimed that any creature in nature does not creates waste substances. The reason for this, waste substances produced at levels by different living organisms can be a useful input orfoodforotherlivingorganisms(King, 2010: 109).

In order to understand the importance of renewable energy sources, it is necessary to explain the environment by the importence of living life. The environment is defined as all physical, biological, social, economic and cultural areas in which people and other living beings maintain relationships and interact during their lifetime. It is necessary to protect the environment from harmful production activities in terms of the continuity of living, the protection of habitats, the growth of healthy communities and sustainable development.

Wastes resulting from production are not only creating environmental pollution, but also they can affecthealth, foodsupply, otherhabitats,economyandmanysub-bases. Today, a large part of environmental pollution arises during effortsto obtain energy. This can be counted as a sign of the humanity unprodactive using of raw materials and energy. Therefore, cleaner and more efficient production steps are needed to prevent waste manufacturing. At this point, compared to the other energy generation tools, renewable energy sources, whichleadtolessnegativeexternalitiesare at theforefront.

\section{ENVİRONMENTAL IMPACTS OF ENERGY PRODUCTION}

As in all production activities, a certain amount of waste arises in theresult of energyproductionactivities. Environmental pollution should not be understoodinterpreteonly as a visiblecontamination of nature. Lead oxide, which is emitted from land vehicles, factory floors, or power plants, causes pollution in toxic gases such as unburned hydrocarbons, carbon monoxide and nitrogen oxides. The environmental effects of these toxic gases can vary. For example, sulfur dioxide gas can be converted into acids by combining with moisture in the air, which can cause acid rain and damages living organisms and structures. Similarly, lead vapor from thermal power plants and vehicle exhausts can lead to behavioraldisorders in livingorganisms (Guney, 2008: 5).

Table 1 givesthemaximum, minimum andaveragevalues of theamounts of $\mathrm{CO}_{2}$ emissionsoccurringduringtheelectricitygenerationphas e, based on energysources. Accordingtothetable, themostpollutingfueltypesarelignite, coal, oilandnaturalgas, whicharecalledfossilfuels. Renewableenergy, thatcalled solar panels, biomass, nuclear,

hydroelectricandwindenergieswhencomparedtofossilfuelt ypes, does not almostcauseenvironmentalpollution in emission of $\mathrm{CO}_{2}$ gas.

Table.1: $\mathrm{CO}_{2}$ Emissions from Electricity Generation

\begin{tabular}{|c|c|c|c|}
\hline \multirow{2}{*}{ Technology } & Mean & Minimum & Maximum \\
\cline { 2 - 4 } & \multicolumn{3}{|c|}{ Ton $\mathrm{CO}_{2} \mathrm{E} / \mathrm{GWh}$} \\
\hline Lignite & 1.054 & 790 & 1.372 \\
\hline Coal & 888 & 756 & 1.310 \\
\hline Oil & 733 & 547 & 935 \\
\hline Natural Gas & 499 & 362 & 891 \\
\hline Solar Panels & 85 & 13 & 731 \\
\hline Biomass & 45 & 10 & 101 \\
\hline Nuclear & 29 & 2 & 130 \\
\hline Hydroelectric & 26 & 2 & 237 \\
\hline Wind & 26 & 6 & 124 \\
\hline
\end{tabular}

Source:World NuclearAssociation (2011, p.6)

These emerging wastes can be classified according to be used the production techniques and quantities. In this study, the environmental effects of energy production can be examined by classifying it according to the types of renewable and non-renewable energy.

\subsection{RenewableEnergySourcesand Environmental Impacts}

Renewable energy is called as sustainable in nature; wind, solar, biomass, wave energy, geothermal and hydrogen. Modern world technology and the economy are largely dependent on petroleum-derived energy sources called fossil sources, but these resources are both harmful and 
limited to the environment. As a result of this the development of renewable energy technologies has become a necessity(Kulebi, 2007: 94).

\subsubsection{Solar Energy}

Solar has vital importance in terms of our ecosystem because life in the world is the main cause of existence and is the first energy source for all living things. It thanks to the solar energy, plants can carry out photosynthesis processes, climatic cycles can occur, and as a result, life on earth can be sustained. Today, the main source of all the energy sources is used, is the solar energy reflected in the world.

Solar energy is basically the shape of electromagnetic energy perceived as heatenergy in theworld (Erturk et al., 2006:33). Human communities have benefited from various forms of solar energy since the day they first appeared. In recent years, solar energy, with the development of technology, has been begun to be used in many different areas of life.

Solar energy has become one of the most widely used renewable energy sources because of the availability of solar energy in large quantities, cheaply and at a constant rate, as well as environmental pollution, operational simplicity, simple technology use and local application (Varinca et al., 2006: 4). In addition to all these advantages, the space required for the installation of the solar panels is small and no special area is required, so that the productive land is not damaged.

The greatest disadvantage of solar energy, which is virtually non-existent in the environmental energy production phase, is that storage and transmission facilities are limited, solar radiation is insufficient during the winter months, instantaneous response to demand and solar panel systems still do not reach the desired efficiency.

\subsubsection{WindEnergy}

Wind consists of temperature, density and pressure differences caused by the fact that the sun can not heat the earth surface equally. As tropical regions get warmer due to more solar rays, polar regions can not get warm enough because they can not get sun rays completely, and air currents flow due to temperature differences between regions. Wind turbines enable the daily use of air currents generated by these differences in the atmosphere by turning them into mechanical energies (Erturk et al., 2006: 35).

Indigenous formation of wind energy, continuity and pollution of the environment make this energy source advantageous. Wind energy is an important alternative to avoid the preference of an environmentally friendly energy source and other harmful production techniques as it does not release carbon, acid or other harmful substances as in other energy sources during the production phase.

Another advantage of wind energy concerns the areas needed for the installation of wind turbines. If the entrepreneur wants to build a wind power plant consisting of 20 turbines he needs $1 \mathrm{~km}^{2}$, but only $1 \%$ of this area is used for turbines and the remaining area can be used for farming or husbandry. Therefore, contrary to other production techniques, wind energy does not come to any pollution ordeformation in naturalareas (Bayrac, 2011: 41). If the wind power plant needs to be removed due to a certain reason in the following periods, the land can be reused for the desired purpose.

The only pollution generated by wind energy is shown as "Noise Pollution". In terms of these types of pollution effects, it can be innocent from the point of view of environmental pollution according to other types of pollution, but it can have effects on the psychology of living things. There is a noise of around 80-85 decibels in the wind power plants. Therefore, leaving a distance of 400-500 meters between the settlements and the wind farms can help to prevent thisnoisefrombeingfelt (Hayli, 2001: 12).

\subsubsection{GeothermalEnergy}

Geothermal energy is a type of energy obtained by the heat of the Earth's core coming out of the surface of heated water as a result of heating the undergroundwater. The use of geothermal energy is based on ancient times. The first users were the ancient Romans, who used the pools and baths to heat them. Today, it is mostly used in houses and hotsprings for heating purpose, also in electricity production and greenhouse cultivation (Cukurcayır et al., 2008: 267).

Geothermal energy is a high performance and defined as a cost-effective, sustainable, renewable and environmentally friendly energy source. Geothermal energy is quite important because environmental damage is near zero in the production phase and it reduces dependence on other fuel types. Nevertheless, as in every production activity, negative externalities emerge.

The first environmental impact of geothermal energy emerges during drilling studies. The land and living life around, the well that is to be opened, may be damaged during these activities. Other effects are noise pollution, underground gasses and drilling mud after drilling. This pollution that emerges after the drilling works can be easily eliminated when essential studies are carried out (Cakın et al., 2005: 346).

The second environmental impact of geothermal energy is related to the construction of pipelines that will carry hot water. The routes through which the pipelines pass, living lifes are affected negatively. In addition, the surface 


remains of the pipelinecause a
visuallyimpureappearance(Cakin et al., 2005: 346).

Another important issue in the use of geothermal energy is related to the re-discharge of the thermal water used. The unconscious release of this water to nature due to the heavy metals contained in the thermal water can pollute the land, water and other resources. The most used technique to prevent this damage is to return water to the source again.

\subsubsection{Hydro Energy}

Hydroelectric power plants are power plants that convert kinetic energy in flowing water into potential electrical energy. It is the most widely used type of renewable energy today and accounts for around $20 \%$ of the world's energy needs (Bozkurt et al., 2015: 329).

One of the greatest advantages of hydro power plants is that almost no carbon emissions as other renewable energy sources, and fighting climate change is beneficial. Another advantage is the contribution of soil erosion and water floods to help reduce water bubbles.

Hydroelectric power plants also have many disadvantages. Especially during the installation process, the surrounding area can be damaged in large quantities. Besides, the natural and wild life in the region can be ended because it floods the area in which it is established. The accumulation of water in the dam reservoir and the expansion of the surface area can facilitate the evaporation of the water. This can cause the salinity of the water to increase and the quality to decrease.

\subsubsection{Biomass Energy}

Biomass is calledthe total mass of living beings that all living beings that have lived or are living in the near future. By burning this mass, biomass energy is revealed. Energy obtained from wood, animal wastes, domestic wastes, unfossilized plants and oil seeds is called biomass energy.

Since the biomassenergy is obtained as a combustion result that causes some carbon release. As a result, the use of biofuel can lead to a decrease in air quality. In addition, industrial activities are currently under way to obtain biofuels. In order to obtain more oil seeds, the forest area is destroyed by turning into agricultural areas and the habitat, who live there, can be damaged. The destruction of the land can lead to erosion, causing the fertile part of the upper layer of the soiltofillrivers, damsandseas.

\subsection{Non-renewable Energy Sources and}

\section{Environmental Impacts}

Energyresourcesthathave been consumed by living things for many years after they are consumed are called nonrenewable energy sources. Today this type of energy includes most commonly used fossil-based energy types such as coal, oil and natural gas in the world. In the modern world, this type of energy is shaped the international relations, internal politics, economics, environmental politics and many social spheres.

\subsubsection{Oil and Natural Gas}

Oil and gas are hydrocarbons in the form of liquid and vapor collected in underground rocks. Fossil fuels are expected to remain market dominance in the coming years as well as being themosttradedcommoditiesworldwide (Montgomery, 2014: 79). Since these fuels have been used especially with modern techniques, they have played and played a major role in the fate of human society.

In addition to the benefits that fossil fuels provide, the world is being paid a hefty price in environmental terms. These fuels, which are widely used today, pollute the environment in three ways. These can be categorized as the pollution that occurs when the fuel is obtained, transported and used.

Oil and natural gas can cause damage to the surrounding area during and after drilling tests. Tanker accidents, which occur after the fuel is obtained, cause damage that can not be compensated for many years for leaks and explosions in pipelines. The toxic gases they burn while burning during the use of fossil fuels, along with creating environmental pollution, are the main causes of greenhouse gas emissions that cause climate change.

\subsubsection{Coal}

Coal is theresidual of substancesthathaveaccumulated, altered and hardened in marshy areas, muddyareas, peatlandsandsimilarecosystems. Thecoal, which is the energy source of the industrial revolution, the locomotive of the machine age, is now called a dirty and undesirable fuel type. Today, despite this adverse outlook towards the coal industry, $25 \%$ of the world's energy is produced from coal and $40 \%$ of the resulting carbon emissions leadtotheuse of coal(Montgomery, 2014: 151).

One issue, which is caused by coal, is the acid rains. Clouds that form as a result of combustion of sulfur dioxide and nitrogen dioxide gases due to combustion process react with oxygen and water then sink into theearthas precipitation (Gautier, 2014: 142).

It relates to radioactivity in the other sorbent originating from the use of coal. Coal contains radioactive elements of thorium and uranium in its content. These elements are thrown from the flame together with ashes during combustion. These elements, which are thrown together with ashes from the wastewater, affect the water resources, soil and livelihoods in the world. When examined in terms of radioactivity, coal plants can be as radioactive as nuclearpowerplants (Hvistendahl, 2007: 2).

\section{ENVIRONMENTAL COMPARISON OF ENERGY SOURCES}

Table 2 shows the environmental impact of energy production and seven different methods of energy 
acquisition were examined in ten different categories. The lines where the activation was detected are marked with a "+" sign, whileothersareleftblank.

There lative environmental impacts of sun, wind, geo thermal and biomassenergy, which are referred to as renewable energy sources in Table 2 , are less than in non- renewable energy sources. At the same time, it is seen that all the energy production type sexamined opportunity cost so it is very important for the future to choose the energy strategies as rational and environmentally sensitive while generatin genergy.

Table.2: Environmental Impacts of Energy Production

\begin{tabular}{|c|c|c|c|c|c|c|c|}
\hline & Solar & Wind & Geothermal & Biomass & Natural gas & Oil & Coal \\
\hline $\begin{array}{l}\text { Limitations of } \\
\text { Resources }\end{array}$ & & & & & + & + & + \\
\hline GreenhouseGas & & & & + & + & + & + \\
\hline Radiation & & & & & & & + \\
\hline AirPollution & & & & + & + & + & + \\
\hline SoilPollution & & & + & & + & + & + \\
\hline WaterPollution & & & + & & + & + & + \\
\hline AcidRain & & & & + & + & + & + \\
\hline Noise & & + & & & & & \\
\hline $\begin{array}{l}\text { Using } \\
\text { WideArea }\end{array}$ & + & + & & + & & & + \\
\hline $\begin{array}{l}\text { Impact on } \\
\text { Living Life }\end{array}$ & & + & + & + & + & + & + \\
\hline
\end{tabular}

Source: World EnergyCouncil 2004: 55

\section{CONCLUSION}

The development of our civilization has become dependent on energy production following a different path from the industrial revolution. Despite the growing energy technologies, production and alternatives, demand has continued to increase day by day. Inthefacing of increasedenergydemand, mankind has been looking at environmental factors from time to time in order to obtain more energy. Today, there are many environmentalrisksthatariseduetohabits of life andenergyproductionand which are predicted to increase its influence in the future.

As stated in the study, every energy production technique has some environmental disadvantages. Although some of the disadvantaged aspects of renewable energy sources, which are still in development stage, are found today, they appear to be more advantageous over the long run compared to conventional energy sources.

Thepointthatpolicymakersandregulators of energy markets must pay attention to is the preference of technologies that will leave minimal damage to the environment while generating energy. In this way, countries will be able to realize their development with the help of indigenous, sustainable and clean resources.

\section{REFERENCES}

[1] Bayraç, H. N. (2011). Küresel Rüzgar Enerjisi Politikaları ve Uygulamaları. UludağÜniversitesi,
İktisadi ve İdari Bilimler Fakültesi Dergisi, 1(30), 37-57.

[2] Bozkurt, S.,\& Tür, R. (2015) Dünyada ve Türkiye'de Hidroelektrik Enerji, Gelişimi ve Genel Değerlendirme, 4. $\mathrm{Su}$ yapıları Sempozyumu, Antalya.

[3] Çakın, A., Gökçen, G., \& Eroğlu, A. (2005). Jeotermal Uygulamaların Çevresel Etkileri: Balçova Jeotermal Bölgesel Isıtma Sistemi Örneği.

[4] Çukurçayır, M. A.,\& SAĞIR, H. (2008). Enerji Sorunu, Çevre ve Alternatif Enerji Kaynaklari. Selçuk Üniversitesi Sosyal Bilimler Enstitüsü Dergisi, (20), 257-278.

[5] Ertürk, F., Akkoyunlu, A., \& Varınca, K. B. (2006). Enerji üretimi ve çevresel etkileri. Türkasya Stratejik.

[6] Gautier, C.(2014). Petrol, Su ve İklim (Sevgi Genç, Çev.), Tubitak Yayınları, Ankara

[7] Güney, E. (2008). Genel ortam kirlenmesi. Palme Yayınc1lik.

[8] Hayli, S. (2001). Rüzgâr enerjisinin önemi Dünya'da ve Türkiye'deki durumu. Fırat Üniversitesi Sosyal Bilimler Dergisi, 11(1), 1-26.

[9] Hvistendahl, M. (2007). Coal ash is more radioactive than nuclear waste. Scientific American, 13.

[10]King, M. (2010). Dünyanın Geçici Bekçileri ( N. Akın, E. Eğilmez, Çev) Carretta Yayın, İstanbul 
[11] Külebi, A. (2007). Türkiye’nin Enerji Sorunları ve Nükleer Gereklilik, Bilgi Yayınevi, Ankara

[12] Montgomery,S. (2014) Küresel Enerjiye Yön Veren Güçler, 2. Bask1, çev. Evra Günhan Şenol, TÜBİTAK Popüler Bilim Kitapları, Ankara

[13] Varınca, K. B.,\& Gönüllü, M. T. (2006). Yenilenebilir Enerji Kaynaklarının Kullanımının Çevresel Olumlu Etkileri. YTÜ Çevre Mühendisliği Bölümü.

[14] World EnergyCouncil (a specialreporttothe), Comparison of energysystemsusing life cycleassessment, July 2004

[15] World Nuclear Association. (2011). Comparison of Lifecycle Greenhouse Gas Emissions of Various Electricity Generation Sources. WNA Report, London. 